\title{
PROFESSOR JAMES RAPHAEL MAINOYA: AN OBITUARY
}

Professor James Raphael Mainoya passed away on the night of 29 May 1990 after a short illness. He was 48 .

Born in Arusha, Tanzania on 20 November 1942, Professor Mainoya did his primary and middle school education in Arusha (1951-1958) and secondary education in Moshi (1959-1964). He obtained his B.Sc. (1966-1968) from the University of East Africa, M.Sc. in Zoology (1969-1971) from the University of Dar-esSalaam and Ph.D. in Zoology (1972-1975) from the University of California, Berkeley.

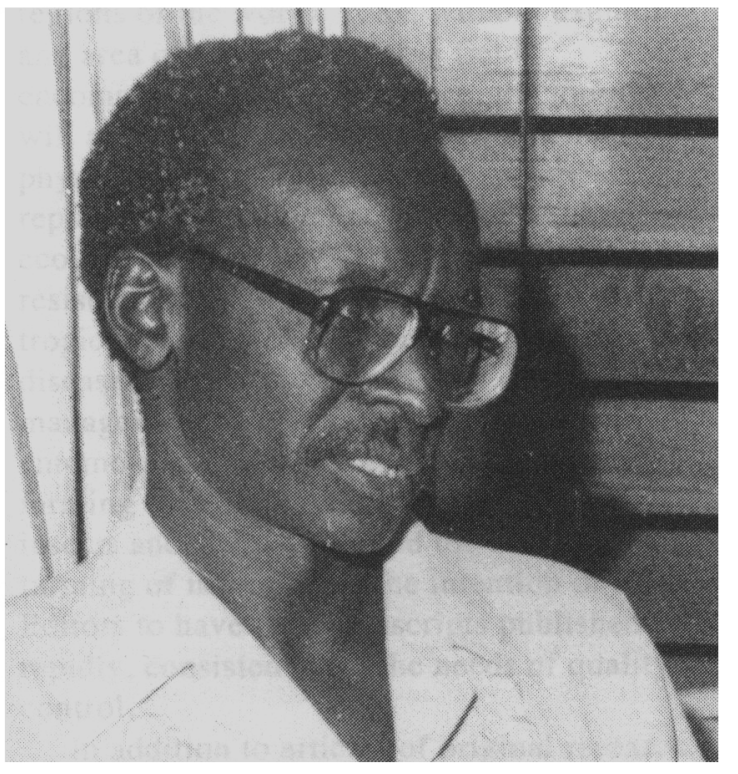

Professor Mainoya was a dedicated academician who devoted his life to scientific research, education and management. He started his career at the University of Dar-es-Salaam as a tutorial assistant in 1969 and rose to the level of full Professor by 1981. At the time of his death, Professor Mainoya had authored a total of 46 major research papers in scientific journals and 14 conference papers, mainly on the physiology of intestinal transport and on functional morphology and histophysiology. His work led to a better understanding of the physiology of intestinal transport in the Tilapia (Sarotherodon mossambicus) adapted to hetero-osmotic environments. He investigated the influence of hormones such as prolactin, cortisol, urotensins, vasointestinal peptides and somatostatin on intestinal transport of water and sodium chloride using various techniques. His studies in functional morphology and histophysiology covered a range of animals including mammals, fish, reptiles and insects. He was interested in the scientific understanding and management of Africa's marine resources as well as in education on the ecological and environmental aspects of Africa's development.

He held several administrative positions at the University of Dar-es-Salaam. He was the head of the Department of Zoology and Marine Biology (1978-1981), the Dean of the Faculty of Science (1982-1988), and Acting Chief Academic Officer (1 June to September 1984). He was also Editor of the Tanzania Journal of Science and Coordinator of the African Biosciences Network for the Eastern and Southern African sub-region (1983-1986).

Professor Mainoya was a member of numerous scientific committees both within and outside Tanzania. He was Chairman of the Serengeti Research Institute Advisory Committee (1978-1980), member of the Academic Board of the African Regional Postgraduate Programme in Insect Science (ARPPIS) (1982-1990), as well as a member of the following: International Organizing Committee of Comparative Endocrinology Symposia (1982-1990); Editorial Advisory Board of the International Journal, Insect Science and its Application (1985-1990); Vice-chairman, African Biosciences Network Regional Executive Committee (1985-1990); Chairman, Board of the Tanzania Fisheries Research Institute (1985-1990); Vice-chairman, Board of the National Museums of Tanzania (1982-1990); Board of the Tanzania National Scientific Research Council (1986-1990); Executive Committee of the Tanzania National Scientific Research Council (1986-1990); Board 
of the Institute of Marine Sciences (Zanzibar) (1982-1990); Chairman, Biosciences Association of Tanzania (1985-1990), and Editorial Advisory Board of Discovery and Innovation (1988-1990).

In death, we have lost a renowned scientist, science administrator, educationist, and one who indeed left a lot for the sons and daughters of Africa to emulate - hard work.

Survived by a wife and six children, Professor James Raphael Mainoya will be greatly missed not only by his family and friends, but also the entire scientific community, including the growing community of insect scientists in Africa. 